\title{
The Antinociceptive Effect of the Leaves and Flowers Ethanolic Extracts of Tabebuia aurea (Silva Manso) Benth \& Hook. F. ex S. Moore
}

\author{
Suellen Maria Albuquerque da Silva ${ }^{1}$, Geraldo José da Silva Neto ${ }^{2}$, Ivenis Raphael Cavalcante do \\ Nascimento ${ }^{1}$, Max Denisson Maurício Viana ${ }^{3}$, Alyne Almeida de Lima ${ }^{1}$, Pedro Henrique Simões \\ Bezerra $^{1}$, Maria Lysete de Assis Bastos ${ }^{1}$, Magna Suzana Alexandre Moreira ${ }^{4}$, Eliane Aparecida \\ Campesatto $^{4^{*}}$ \\ ${ }^{I}$ Universidade Federal de Alagoas - Escola de Enfermagem e Farmácia, Maceió, Alagoas; ${ }^{2}$ Universidade Federal \\ de Alagoas - Instituto de Química e Biotecnologia, Maceió, Alagoas; ${ }^{3}$ Universidade Federal de Alagoas - Instituto \\ de Ciências Biológicas e da Saúde, Maceió, Alagoas; ${ }^{4}$ Universidade Federal de Alagoas - Departamento de \\ Farmacologia, Instituto de Ciências Biológicas e da Saúde, Maceió, Alagoas Brazil.
}

\begin{abstract}
In view of the traditional use of Tabebuia aurea for treating pain and inflammation, the antinociceptive pharmacological potential of T. aurea ethanolic extracts (TAEE) was investigated through in vivo experimental models. First, the MTT assay was conducted to determine the potential cytotoxicity of the TAEEs. Afterwards, the acetic acid-induced writhing test and the formalin-, and glutamate-induced nociception tests were performed on Swiss adult mice treated with TAEEs (100 and $200 \mathrm{mg} / \mathrm{kg}$ doses, p.o.), or saline solution (control groups, $10 \mathrm{~mL} / \mathrm{kg}$, p.o.), or standard drugs: dipyrone $40 \mathrm{mg} / \mathrm{kg}$ (p.o.), and morphine 5,7 $\mathrm{mg} / \mathrm{kg}$ (i.p). In the MTT assay, none of the tested concentrations demonstrated signals of cytotoxicity. In the in vivo experimental models of acetic acid-induced writhing and glutamate-induced nociception, all TAEEs doses were able to statistically reduce the nociceptive response. However, the TAEEs did not show significant decrease in the amount of time that the animals spent licking the stimulated paw in the neurogenic phase of formalin-induced nociception test, differently of what was observed in the inflammatory phase. The results showed that T. aurea species induce an antinociceptive effect in rodents, which encourages the study of new drugs and contributes to the research on natural products.
\end{abstract}

Keywords: Analgesics; Nociception; Medicinal plants; Tabebuia aurea; Mice.

*Author for correspondence: eliane_campesatto@hotmail.com 


\section{INTRODUCTION}

Pain is associated with inflammation, as it is described as one of its five classic signs, also characterized by heat, redness, swelling and loss of function ${ }^{1}$. Pain and inflammation exist in the acute and chronic stages of most noxious stimuli and in many diseases, and it has great physiological significance in tissues maintenance and integrity. Acute and chronic pains are differentiated by the fact that the first one occurs by nociceptive stimulus, while the second one is often caused by inflammation or neuropathies ${ }^{2}$.

There are several therapies for the treatment of pain and inflammation available in the market. However, the adverse effects and, in some cases, the low effectiveness limit their use ${ }^{3}$. Steroidal and non-steroidal anti-inflammatory drugs are used in conventional treatments, as well as drugs that alter the course of the disease such as: cyclosporin, chloroquine, amongst others. The long-term use of these drugs can cause hepatic and gastrointestinal disorders, which encourages the search on new treatments ${ }^{4}$.

The study of medicinal plants has become a strategy in the search of pharmacological alternatives due to their ethnopharmacological use. In this context, research about plant species traditionally used is needed to establish scientific evidence of their therapeutic efficacy and safety. Tabebuia is a genus in the Bignoniaceae family that has been well described in the scientific literature. Studies of different species of this genus have shown significant results for antinociceptive, anti-inflammatory, antioxidant, antibacterial, antifungal, diuretic and anticoagulant activities ${ }^{5}$. These activities are possibly attributed to secondary metabolites, such as steroids, flavonones, flavonols, flavonoids, saponins, tannins, triterpenoids and xanthones ${ }^{6}$.

Therefore, Tabebuia aurea, known as yellow ipê, is confirmed as a species with wide potential for scientific research, which may result in the discovery of new safe and effective compounds of pharmacological interest. In view of the traditional use of Tabebuia aurea for treating pain and inflammation, this study aims to evaluate the antinociceptive pharmacological potential of $T$. aurea.

\section{MATERIALS AND METHODS}

\section{Collection and identification of T. aurea}

The leaves and flowers samples of T. aurea were collected in January 2015 in the city of Maceió, in a vegetation of the Atlantic Forest at the Federal University of Alagoas (geographical coordinates: $9^{\circ} 33^{\prime} 23.6^{\prime \prime} \mathrm{S}$, 35 $5^{\circ} 46^{\prime} 39.6^{\prime \prime} \mathrm{W}$ ). The botanical identification was carried out by the MAC Herbarium of the Environmental Institute of the State of Alagoas, where the voucher specimen was deposited and registered under MAC Registration Number 21433.

\section{T. aurea extracts preparation}

The leaves and flowers of $T$. aurea were dried in an oven under controlled temperature $\left(48 \pm 2{ }^{\circ} \mathrm{C}\right)$ for $24 \mathrm{~h}$ and then powdered. The TAEEs were obtained by exhaustive maceration, in which the extractive solvent (ethanol P.A.) was added every 72 hours for 9 days, followed by filtration until a lighter colored liquid was obtained. Then, both extracts obtained by filtration were concentrated on a rotary evaporator under controlled temperature $\left(45^{\circ} \mathrm{C} \pm 1{ }^{\circ} \mathrm{C}\right.$ ) for $24 \mathrm{~h}$. 


\section{MTT in vitro cell viability assay}

J774 lineage macrophages were plated in a 96-well microplate ( $1 \times 10^{5}$ cells per well), cultured in $200 \mu \mathrm{L}$ Roswell Park Memorial Institute (RPMI) medium supplemented with $10 \%$ fetal bovine serum and $1 \mathrm{~mL}$ of non-essential amino acids (pyruvate and glutamine at concentrations of $100 \mathrm{mM}$ and $200 \mathrm{mM}$ respectively). The plated cells were incubated overnight for better adherence at $37 \pm 1{ }^{\circ} \mathrm{C}$ in a $5 \% \mathrm{CO}_{2}$ atmosphere, prior to treatment. The cells were treated with leaves and flowers TAEEs at concentrations of $100,10,1$, and $0.1 \mu \mathrm{g} / \mathrm{mL}$, as well as the standard drug (dipyrone, concentrations of $100,10,1$, and $0.1 \mu \mathrm{mol} / \mathrm{mL}$ ) and also controls (medium; $0.1 \%$ dimethylsulfoxide - DMSO - vehicle; and Triton ${ }^{\text {TM }} \mathrm{X}-100$ ). Since Triton ${ }^{\mathrm{TM}} \mathrm{X}-100$ is capable of promoting cell lysis, it was used as the standard for cell death. Following treatment, the cells were kept under the same conditions as described above for $24 \mathrm{~h}$. At the end of the incubation period, the supernatant was discarded; then $100 \mu \mathrm{L}$ of 0.5 $\mathrm{mg} / \mathrm{mL}$ MTT solution was added to each well and reincubated for $1 \mathrm{~h}$ under the same conditions in order to promote the reduction reaction of MTT into formazan. After this period, the supernatant was discarded and the cells were lysed with $100 \mu \mathrm{l}$ of DMSO (solubilizing the formazan precipitate). The wells were analyzed in a microplate reader (TP-Reader, ThermoPlate) at $530 \mathrm{~nm}$ wavelength for the quantitative determination of formazan.

\section{Evaluation of the antinociceptive potential effect of TAEES in in vivo experimental models}

\section{Animals}

Swiss albino mice, both male and female, adults (6 - 8 weeks), weighing $25-35 \mathrm{~g}$ provided by the Central Animal Facility of UFAL were used for the in vivo experimental models. They were arranged in groups of 6 animals per cage and were housed in a microisolator housing system with filtered airflow, in the Cell Biology Laboratory (LBC/ICBS/UFAL). The animals were acclimatized at a controlled temperature $\left(22 \pm 2{ }^{\circ} \mathrm{C}\right)$ in a light-dark cycle of $12 \mathrm{~h}$ each (dark phase from 06:00 p.m. to 06:00 a.m.) with water and food ad libitum. Before the experiments, the animals in the groups treated with oral substances (p.o.) were fasted for $6 \mathrm{~h}$, with water ad libitum. The animals used in this study were handled following all the protocols established by the National Council for Animal Experimentation Control (CONCEA) and approved by the Ethics Committee on the Use of Animals of UFAL (CEUA/UFAL) under the protocol number 055/2016.

\section{Acetic acid-induced writhing test ${ }^{7}$}

Abdominal writhing in mice was induced by intraperitoneal (i.p.) injection of acetic acid $(0.6 \%$ solution, $0.1 \mathrm{~mL} / 10 \mathrm{~g})$ which acts as a nociceptive stimulus in the mouse, measured through a sequence of contractions of the abdominal musculature that may be accompanied by the extension of their lower limbs. Animals were treated with leaves and flowers TAEEs, vehicle (saline solution - $\mathrm{NaCl} 0,9 \%$ - negative control group), or dipyrone (positive control group) 40 minutes before nociceptive stimulus. The number of writhes was counted 5 minutes after the acetic acid administration, for 20 minutes.

\section{Formalin-induced nociception assay ${ }^{8}$}


The test was conducted with the same distribution of groups of the acetic acid-induced writhing test, in which only the positive group received a different standard drug (morphine). After 40 minutes of the treatments, $20 \mu \mathrm{L}$ of $2.5 \%$ formalin (formaldehyde diluted in saline) were administered by a subplantar injection (s.pl.) on the dorsal surface of the animal's hind paw. After formalin administration, the period in which the animal remained licking the paw was timed, that being the indicative criterion of nociception. The time recording was established in two periods: the first phase for the first 5 minutes of the test, followed by a 10 minutes break, and then the second phase for the next 15 minutes, which are related to the neurogenic (or acute) and to the inflammatory phases, respectively.

\section{Glutamate-induced nociception assay ${ }^{9}$}

The test was conducted with the same distribution of groups of the formalin-induced nociception test. After 40 minutes of the treatment, $20 \mu \mathrm{L}$ of glutamate (at a dose of 30 $\mu \mathrm{mol} / \mathrm{paw}$ ) were administered (s.pl.) on the dorsal surface of the hind paw of the animal. The period in which the animals remained licking the paw was timed for 15 minutes after glutamate administration, which is the parameter considered parameter as the indicative of nociceptive stimulus response.

\section{Statistical analysis}

The results were expressed as mean \pm standard error of the mean (S.E.M.) and the statistical differences between the means of the groups were analyzed using Analysis of Variance (ANOVA) followed by the Dunnett's test. The values of the results were considered significant when $* p<0.05$. Analyzes were performed in the software GraphPad Prism® version 5.

\section{RESULTS}

\section{Evaluation of the cell viability}

The results showed on Figure 1 express the effects of the treatment with leaves and flowers TAEEs $(0.1,1.0,10$, and $100 \mu \mathrm{g} / \mathrm{mL})$ on $\mathrm{J} 774$ murine macrophages on the cell viability assay from the MTT colorimetric method. It was possible to observe that cell viability was not affected in any of the TAEEs tested concentrations, differently to the same concentrations of dipyrone, the standard analgesic drug, which reduced cell viability at concentrations equal to and greater than $1 \mu \mathrm{M}(p<0.001)$. As expected, there was no cell death in medium and DMSO groups. Therefore, it can be said that none of the extracts in any of its doses studied showed cytotoxicity, thus allowing continuation of in vivo assays. 


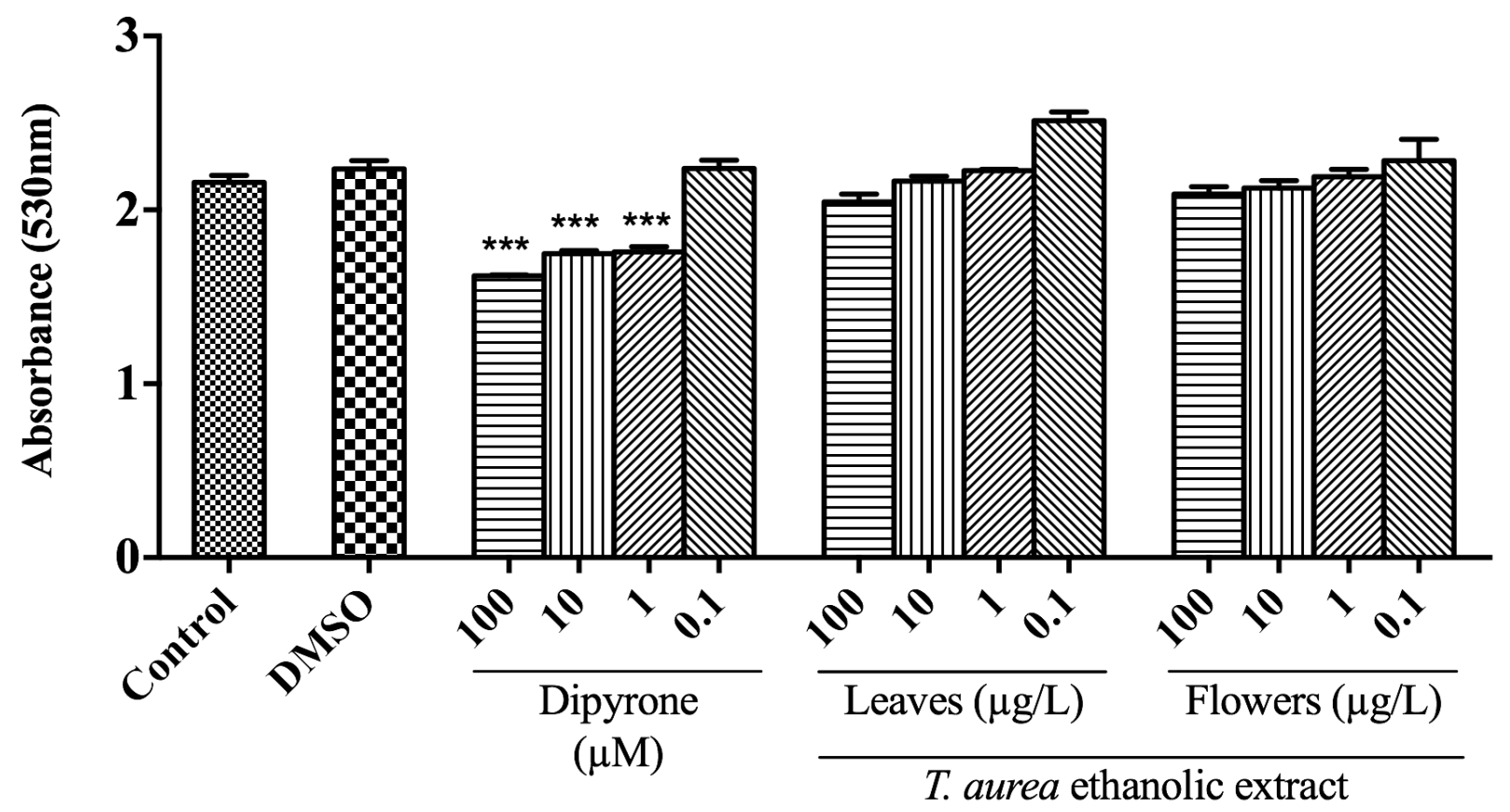

Figure 1. Effect of Tabebuia aurea ethanolic extracts (TAEEs) from leaves and flowers on the cell viability by MTT assay. Control (medium); DMSO (0.1\%); Dipyrone (100, 10, 1, and $0.1 \mu \mathrm{M})$; TAEEs from leaves and flowers $(100,10,1$, and $0.1 \mu \mathrm{g} / \mathrm{ml})$. The columns and bars represent, respectively, the mean \pm S.E.M. in triplicate through a One-Way ANOVA followed by the Dunnett's test, in which was considered significant when ***p $<0.001$

\section{Evaluation of the antinociceptive potential TAEEs in in vivo experimental models}

Acetic acid-induced writhing test

In Figure 2 it is possible to observe that in the experimental model of acetic acidinduced writhing all doses of both EETAs were able to statistically reduce the number of writhes ( $p<0.001)$, compared to the control group, similar to the drug standard Dipyrone $(\mathrm{p}<0.001)$. 


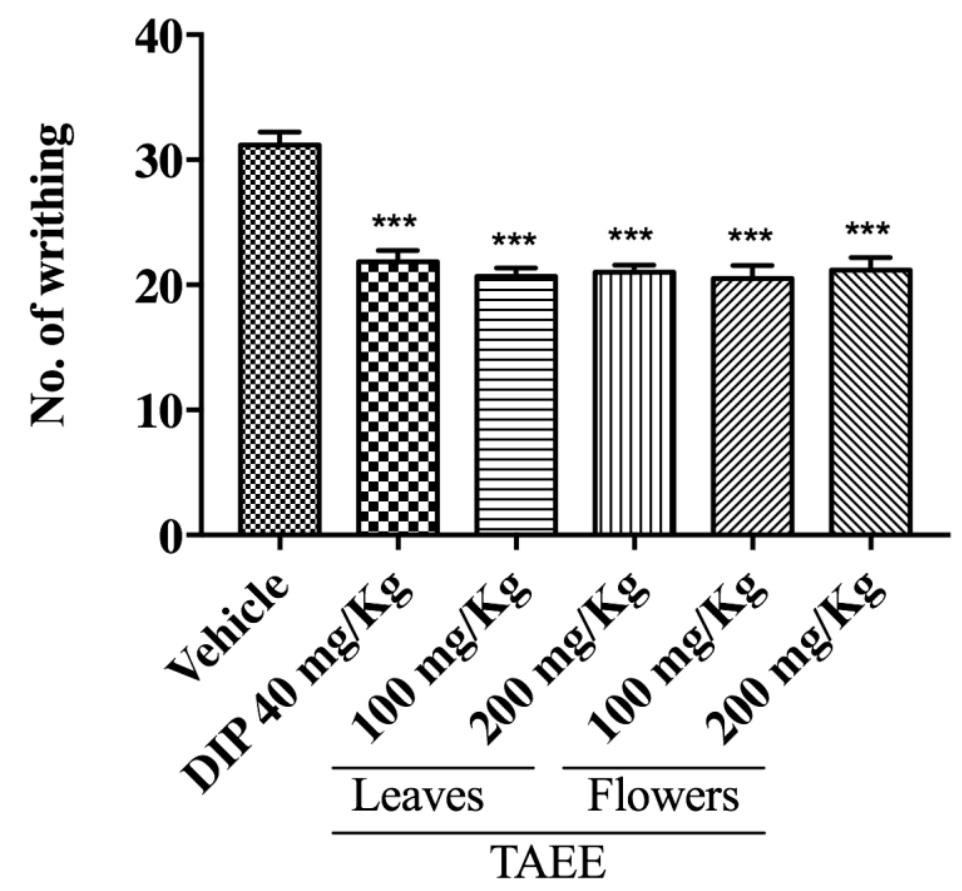

Figure 2. Effect of Tabebuia aurea ethanolic extracts (TAEEs) from leaves and flowers on the acetic acid-induced abdominal writhing test. Vehicle (saline solution $10 \mathrm{~mL} / \mathrm{kg}$, p.o.); DIP (dipyrone $40 \mathrm{mg} / \mathrm{kg}$, p.o.); TAEE (Tabebuia aurea ethanolic extracts from leaves and flowers at 100 and $200 \mathrm{mg} / \mathrm{kg}$, p.o.). The columns and bars represent, respectively, the mean \pm S.E.M. of each group $(n=6)$ through a One-Way ANOVA followed by the Dunnett's test, in which was considered significant when $* * * p<0.001$.

Table 1 shows that, in the acetic acid-induced writhing test, the decrease of the number of writhing was statistically significant $(p<0.001)$ for all the TAEEs tested doses, when compared to the negative control group (vehicle - saline solution). Similar result was observed to the standard drug dipyrone $(\mathrm{p}<0.001)$. The table also shows that leaves and flowers TAEEs at 100 and $200 \mathrm{mg} / \mathrm{kg}$ doses presented a percentage of writhing inhibition equal to $33.69 \%, 34.23 \%, 32.63 \%$, and $32.08 \%$, respectively. The standard drug (dipyrone) exhibited a percentage of inhibition of $29.96 \%$, wherein this percentage is lower than those showed by both TAEEs.

Table 1. Absolute values of number of writhing and percentage of nociceptive inhibition after treatment with Tabebuia aurea ethanolic extracts (TAEE 100 and $200 \mathrm{mg} / \mathrm{kg}$ ) from leaves and flowers on the acetic acid-induced writhing test in mice.

\begin{tabular}{ccc}
\hline Groups & Number of writhing & \% of inhibition \\
\hline Vehicle $(10 \mathrm{~mL} / \mathrm{Kg})$ & $31.17 \pm 1.05$ & - \\
Dipyrone $(40 \mathrm{mg} / \mathrm{Kg})$ & $21.83 \pm 0.91 * * *$ & $29.96 \%$ \\
Leaves TAEE $(100 \mathrm{mg} / \mathrm{Kg})$ & $20.67 \pm 0.67 * * *$ & $33.69 \%$ \\
Leaves TAEE $(200 \mathrm{mg} / \mathrm{Kg})$ & $21 \pm 0.58 * * *$ & $32.63 \%$ \\
Flowers TAEE $(100 \mathrm{mg} / \mathrm{Kg})$ & $20.5 \pm 1.06 * * *$ & $34.23 \%$ \\
Flower TAEE $(200 \mathrm{mg} / \mathrm{Kg})$ & $21.17 \pm 1.01 * * *$ & $32.08 \%$ \\
\hline
\end{tabular}

Vehicle (saline solution $10 \mathrm{~mL} / \mathrm{kg}$, p.o.); Dipyrone (40 mg/kg, p.o.); TAEE (Tabebuia aurea ethanolic extracts from leaves and flowers at 100 and $200 \mathrm{mg} / \mathrm{kg}$, p.o.). The values in the second and third columns represent the mean \pm S.E.M. $(\mathrm{n}=6)$ through a One-way ANOVA followed by the Dunnett's test, in which it was considered significant when $* * * p<0.001$.

\section{Formalin-induced nociception test}

The effect of TAEEs on the different phases of the formalin-induced nociception test in mice can be observed in Figure 3. In the first phase none of the doses of both 
TAEEs was able to significantly reduce the time of paw licking after inoculation of the nociceptive stimulus (Figure 3A). The opposite of what was recorded in the second phase, since the treatment with the two doses of both TAEEs statistically reduced this parameter $(\mathrm{p}<0.001)$ - Figure 3B. In addition, the treatment with morphine also decreased the licking time in both phases $(\mathrm{p}<0.001)$.

A Phase 1 - Neurogenic Pain

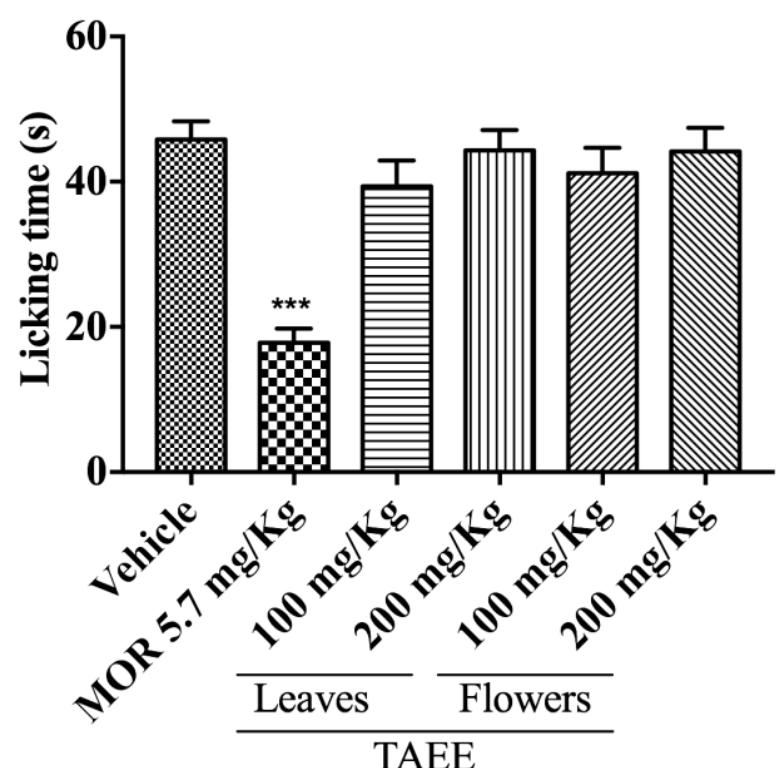

\section{B Phase 2 - Inflammatory Pain}

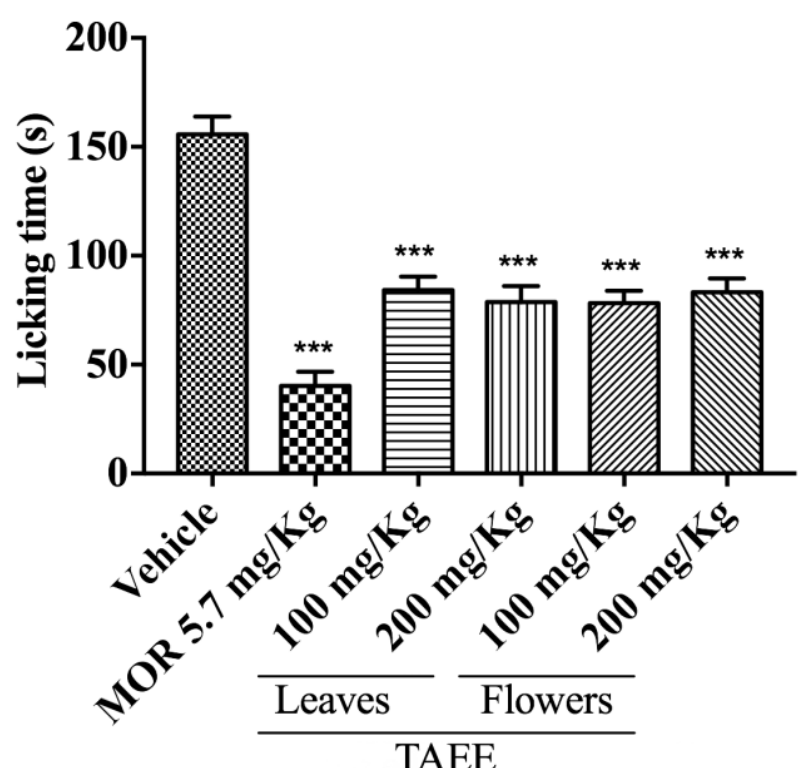

Figure 3. Effect of Tabebuia aurea ethanolic extracts (TAEEs) from leaves and flowers on the formalin-induced nociception test. A: Phase 1 (neurogenic pain); B: Phase 2 (inflammatory pain). Vehicle (saline solution $10 \mathrm{~mL} / \mathrm{kg}$, p.o.); MOR (morphine $5.7 \mathrm{mg} / \mathrm{kg}$, i.p.); TAEE (Tabebuia aurea ethanolic extracts from leaves and flowers at 100 and $200 \mathrm{mg} / \mathrm{kg}$, p.o.). The columns and bars represent, respectively, the mean \pm S.E.M. of each group $(\mathrm{n}=6)$ through a One-Way ANOVA followed by the Dunnett's test, in which was considered significant when *** $p<$ 0.001 .

The absolute values of the lick time as well as the percent inhibition are described in Table 2. The percentages of inhibition mediated by the standard drug were $61.10 \%$ and $74.20 \%$ for $1^{\text {st }}$ and $2^{\text {nd }}$ phases, respectively. Oral treatment with leaves and flowers TAEEs presented a statistically significant decrease in the nociceptive response, which showed percentages of inhibition of $45.94 \%, 49.79 \%, 49,47 \%$, and $46.58 \%$, respectively, for $2^{\text {nd }}$ phase.

Table 2. Absolute values of licking time and percentage of nociceptive inhibition after treatment with Tabebuia aurea ethanolic extracts (TAEE 100 and $200 \mathrm{mg} / \mathrm{kg}$ ) from leaves and flowers on the formalin-induced nociception test in mice.

\begin{tabular}{ccccc}
\hline \multirow{2}{*}{ Treatments } & \multicolumn{4}{c}{ Paw licking time (s) } \\
\cline { 2 - 5 } & Phase 1 & \% of inhibition & Phase 2 & \% of inhibition \\
\hline Vehicle $(10 \mathrm{~mL} / \mathrm{Kg})$ & $45.83 \pm 2.45$ & - & $155.7 \pm 8.17$ & - \\
Morphine $(5.7 \mathrm{mg} / \mathrm{Kg})$ & $17.83 \pm 1.96 * * *$ & $61.10 \%$ & $40.17 \pm 6.57 * * *$ & $74.20 \%$ \\
Leaves TAEE $(100 \mathrm{mg} / \mathrm{Kg})$ & $39.33 \pm 3.55$ & $14.18 \%$ & $84.17 \pm 6.17 * * *$ & $45.94 \%$ \\
Leaves TAEE $(200 \mathrm{mg} / \mathrm{Kg})$ & $44.33 \pm 2.81$ & $3.27 \%$ & $78.67 \pm 7.46 * * *$ & $49.47 \%$ \\
Flowers TAEE $(100 \mathrm{mg} / \mathrm{Kg})$ & $41.17 \pm 3.50$ & $10.17 \%$ & $78.17 \pm 5.68 * * *$ & $49.79 \%$ \\
Flowers TAEE $(200 \mathrm{mg} / \mathrm{Kg})$ & $44.17 \pm 3.28$ & $3.62 \%$ & $83.17 \pm 6.40 * * *$ & $46.58 \%$ \\
\hline
\end{tabular}

Phase 1 (neurogenic phase); Phase 2 (inflammatory pain). Vehicle (saline solution, $10 \mathrm{~mL} / \mathrm{kg}$, p.o.); morphine $(5.7 \mathrm{mg} / \mathrm{kg}$, i.p.); TAEE (Tabebuia aurea ethanolic extracts from leaves and flowers at 100 and $200 \mathrm{mg} / \mathrm{kg}$, p.o.). The values in the second through fourth columns represent the mean \pm S.E.M. $(n=6)$ through a One-way ANOVA followed by the Dunnett's test, in which it was considered significant when $* * * p<0.001$. 


\section{Glutamate-induced nociception assay}

The effect of TAEEs on the glutamate-induced nociception test is showed in Figure 4, in which nociceptive response represents the period in which the animal spends licking its paw - which is the same parameter recorded in the formalin-induced nociception test. All of the groups (including positive control group) statistically decrease $(\mathrm{p}<0.001)$ the nociception response when compared to the vehicle group.

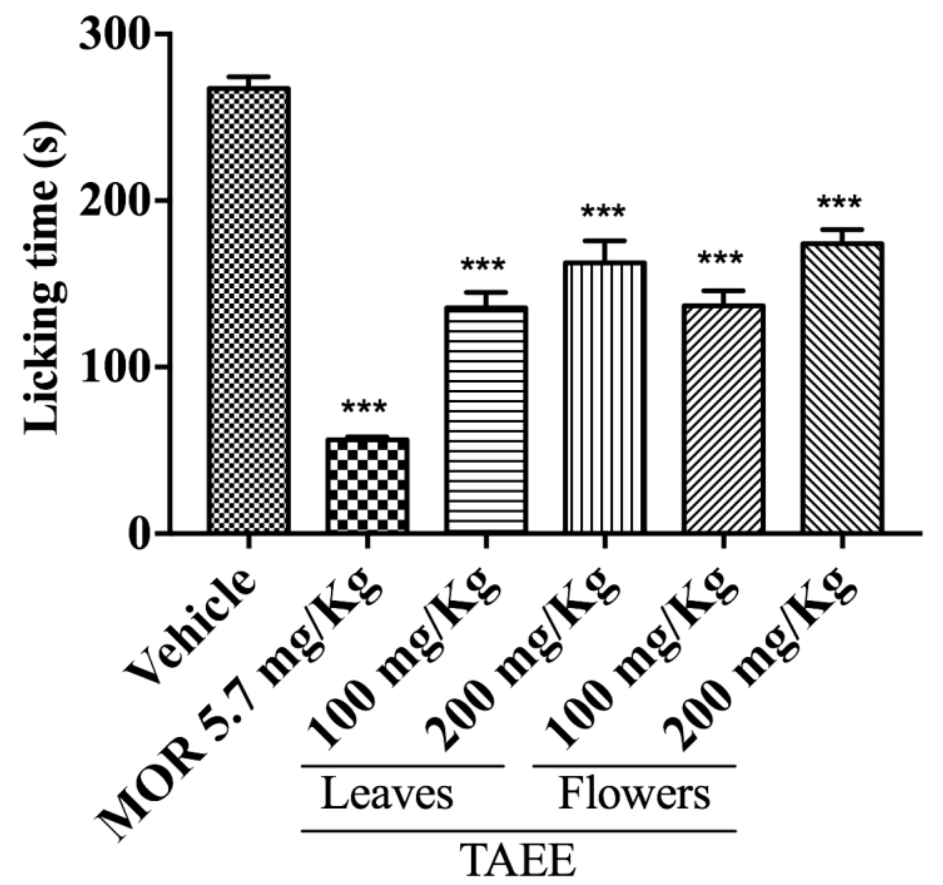

Figure 4. Effect of Tabebuia aurea ethanolic extracts (TAEEs) from leaves and flowers on the glutamate-induced nociception assay. Vehicle (saline solution $10 \mathrm{~mL} / \mathrm{kg}$, p.o.); MOR (morphine $5.7 \mathrm{mg} / \mathrm{kg}$, i.p.); TAEE (Tabebuia aurea ethanolic extracts from leaves and flowers at 100 and $200 \mathrm{mg} / \mathrm{kg}$, p.o.). The columns and bars represent, respectively, the mean \pm S.E.M. of each group $(n=6)$ through a One-Way ANOVA followed by the Dunnett's test, in which was considered significant when $* * * p<0.001$.

The Table 3 demonstrate absolute values of the lick time as well as the percent inhibition. Animals treated with both TAEEs presented a percentage of inhibition of the nociceptive response of $49.25 \%, 39.23 \%, 48.77 \%$ and $35.00 \%$, where the doses of TAEE of leaves and flowers were 100 and $200 \mathrm{mg} / \mathrm{kg}$, respectively. The standard drug used as a positive control was morphine, which inhibited $78.88 \%$ of the nociceptive response.

Table 3. Absolute values of licking time and percentage of nociceptive inhibition after treatment with Tabebuia aurea ethanolic extracts (TAEE 100 and $200 \mathrm{mg} / \mathrm{kg}$ ) from leaves and flowers on the glutamate-induced nociception test in mice.

\begin{tabular}{ccc} 
Treatments & Paw licking period (s) & \% of inhibition \\
\hline Vehicle $(10 \mathrm{~mL} / \mathrm{Kg})$ & $267.40 \pm 6.84$ & - \\
Morphine $(5.7 \mathrm{mg} / \mathrm{Kg})$ & $56.47 \pm 1.54 * * *$ & $78.88 \%$ \\
Leaves TAEE $(100 \mathrm{mg} / \mathrm{Kg})$ & $135.70 \pm 9.15 * * *$ & $49.25 \%$ \\
Leaves TAEE $(200 \mathrm{mg} / \mathrm{Kg})$ & $162.50 \pm 13.35 * * *$ & $39.23 \%$ \\
Flowers TAEE $(100 \mathrm{mg} / \mathrm{Kg})$ & $137.00 \pm 8.94 * * *$ & $48.77 \%$ \\
Flowers TAEE $(200 \mathrm{mg} / \mathrm{Kg})$ & $173.80 \pm 8.59 * * *$ & $35.00 \%$ \\
\hline
\end{tabular}

Vehicle (saline solution, $10 \mathrm{~mL} / \mathrm{kg}$, p.o.); morphine $(5.7 \mathrm{mg} / \mathrm{kg}$, i.p.); TAEE (Tabebuia aurea ethanolic extracts from leaves and flowers at 100 and $200 \mathrm{mg} / \mathrm{kg}$, p.o.). The values in the second and third columns represent the mean \pm S.E.M. $(\mathrm{n}=6)$ through a One-way ANOVA followed by the Dunnett's test, where it was considered significant when $* * * p<0.001$. 


\section{DISCUSSION}

Many medicinal plants preparations are marketed without proven quality and may be considered unsafe for use, leaving users at risk of toxicity, since those have not been tested for pharmacological and/or toxicological effects ${ }^{10}$.

Thus, after the TAEEs were obtained, an in vitro toxicity test was initially conducted using the MTT assay, which evaluates the mitochondrial activity, and consequently cell viability, through quantification of the MTT salt reduction into Formazan by dehydrogenase enzymes in the mitochondria ${ }^{3}$.

In order to get substances appropriately approved for use from in vitro toxicity tests, they should not cause cells death or impair and/or affect their primary and secondary functions ${ }^{11}$. As shown in the results, no cytotoxicity signals were observed at any of the tested concentrations of both TAEEs.

Studies that assessed the cellular viability of species of Tabebuia genus showed no sign of cytotoxicity even at a maximum concentration of $1.0 \mathrm{mg} / \mathrm{mL}$ for $T$. impetiginosa ${ }^{12}$, or only suggested cytotoxicity at concentrations of $800 \mu \mathrm{g} / \mathrm{mL}$ or higher for T. serratifolia ${ }^{13}$.

A study on the biological potential of T. aurea, carried out by Santos et al., evaluated the in vitro toxicity of ethanol extracts of flowers and leaves of $T$. aurea at concentrations of $1,0.5,0.2$ and $0.1 \mathrm{mg} / \mathrm{mL}$ - higher concentrations compared to the ones used in this study - also by the MTT assay. The results showed no signs of cytotoxicity at any of the tested concentrations of leaf extract, but the flower extract at $1 \mathrm{mg} / \mathrm{mL}$ reduced cell viability ${ }^{14}$.

The results of the present study support the findings described in the literature on $T$. aurea and other species of the genus. Thus, species of Tabebuia do not show cytotoxicity in usual concentrations, demonstrating safety in their use. However, cautiousness should be applied for use at a significantly high amount, which could possibly culminate in a toxic hazard.

Subsequently, the investigation of its antinociceptive potential was carried out. Studies on antinociceptive activity using plants traditionally known by their therapeutic properties are widely performed, aiming to support their traditional use with scientific evidence, besides contributing to the search for more potent analgesics that show lower side effects ${ }^{15}$.

The first assay performed for the assessment of the TAEE antinociceptive potential was the acetic acid-induced writhing test. The results of this study demonstrated that all leaves and flowers TAEEs doses were able to statistically reduce the number of writhes in response to the nociceptive stimulus. However, there were no statistical differences in this parameter when the 100 and $200 \mathrm{mg} / \mathrm{kg}$ doses of both extracts were compared to each other.

Chandrika et al. also obtained statistically significant results using the same species but using alcoholic and aqueous extracts from the leaves in larger doses (250 and 500 $\mathrm{mg} / \mathrm{kg}$, p.o. $)^{16}$.

Using the same experimental model, Lee et al. demonstrated that the ethanol extract of T. avellanedae internal stem bark induced a statistically significant antinociceptive effect at doses of $200 \mathrm{mg} / \mathrm{kg}$ and $400 \mathrm{mg} / \mathrm{kg}$, orally ${ }^{17}$. It was similar to the other representative of the genus, T. hypoleuca for all tested doses of the methanol extract of the stem $(150,300 \text { and } 500 \mathrm{mg} / \mathrm{kg})^{18}$.

The aforementioned studies results support the findings presented in this study, indicating an antinociceptive potential effect, which led to other experimental protocols that intended to achieve a better characterization of this pharmacological property. 
The second in vivo experimental model conducted was the formalin-induced nociception test. The stereotyped response in the animal is divided into two phases: in the first phase, called neurogenic, there is an uninterrupted stimulation of the peripheral nociceptors, resulting in the depolarization of them and the propagation of the signal to the CNS. This phase occurs shortly after the formalin stimulus and lasts for about five minutes ${ }^{8}$. None of the tested doses from both TAEEs were able to statistically reduce the time the animal spent licking the paw after administration of the phlogistic agent.

After five minutes of the neurogenic phase, a minimal or absent nociceptive response occurs, lasting for a period of ten minutes, in which it is not evaluated the parameter of nociceptive response. The following fifteen minutes are defined as the second (inflammatory) phase, in which the inflammatory mediators are released, such as prostaglandins, leukotrienes, histamine, bradykinin, among others, that are able to lower the threshold of excitability of the nociceptors and therefore activating them more easily and stimulating a nociceptive response increase ${ }^{8}$. Both $100 \mathrm{mg} / \mathrm{kg}$ and 200 $\mathrm{mg} / \mathrm{kg}$ doses of the TAEEs were able to statistically decrease the licking time in the inflammatory phase caused by the noxious stimulus.

The results obtained in the morphine treated group, opioid drug used as positive control, showed that it was able to statistically inhibit the licking time in both phases of the test.

Chandrika et al., using the same species as in the present study, found significant inhibition of the licking time during the first phase for $250 \mathrm{mg} / \mathrm{kg}$ and $500 \mathrm{mg} / \mathrm{kg}$ doses using alcoholic extract from leaves, and for $500 \mathrm{mg} / \mathrm{kg}$ dose using the aqueous extract also from leaves. In addition, the inhibition of the same parameter occurred in the second phase for both tested doses of the extracts - which was observed in the results of the present study ${ }^{16}$.

The findings in the literature are similar to the results obtained with leaves and flowers TAEEs, and it indicates that the increase in the tested doses may be able to induce a more statistically significant response during the neurogenic phase of the test.

Then, in order to better characterize the antinociceptive potential of $T$. aurea, the glutamate-induced nociception test was performed. The results obtained from the use of the leaves and flowers ethanolic extracts of $T$. aurea showed that they were able to statistically inhibit the licking time after administration of glutamate, for both doses of each extract.

Glutamate acts as an excitatory neurotransmitter, leading to the generation of action potential by nociceptors and the propagation of this potential to the CNS pain perception sites 9 .

It is known that nociception caused by glutamate is triggered by the activation of NMDA and non-NMDA type receptors, wherein the activation of the L-arginine-nitric oxide pathway is extremely important ${ }^{9}$. Thus, it is possible that the secondary metabolites from the TAEEs are negatively modulating the nociceptive stimulus caused by glutamate, either via the aforementioned receptors or via L-arginine-nitric oxide.

Therefore, based on the above, the leaves and flowers ethanolic extracts of T. aurea, at doses of $100 \mathrm{mg} / \mathrm{kg}$ and $200 \mathrm{mg} / \mathrm{kg}$, induce an antinociceptive effect.

\section{CONCLUSION}

T. aurea ethanolic extracts did not presented toxicity at cellular level and it showed antinociceptive effects in animals, which corroborates the traditional use of $T$. aurea. Also, the results contribute to the research on natural products, mainly of medicinal 
plants that may be used as alternative or complementary therapy, leading to the development of new analgesic drugs.

\section{REFERENCES}

1. Ji RR, Chamessian A, Zhang YQ. Pain regulation by non-neuronal cells and inflammation. Science. 2016; 354(6312): 572-577.

2. Prá SDT, Ferro PR, Milioli AM, Rigo FK, Chipindo OJ, Camponogara C, et al. Antinociceptive activity and mechanism of action of hydroalcoholic extract and dichloromethane fraction of Amphilophium crucigerum seeds in mice. $J$ of Ethnopharmacol. 2017; 195: 283-97.

3. Silva EMF, Nascimento RBC, Barreto FS, Filho MOM, Griz SAS, Santos AF, et al. Estudo in vitro do potencial citotóxico da Annona muricata L [In vitro study of the cytotoxic potential of Annona muricata L]. Rev Ciênc Farm Basic Apl. 2015; 36 (2): 277-83.

4. Oliveira FFB, Araújo JCB, Pereira AF, Brito GAC, Gondim DV, Ribeiro RA, et al. Antinociceptive and anti-inflammatory effects of Caryocar coriaceum Wittm fruit pulp fixed ethyl acetate extract on zymosan-induced arthritis in rats. $J$ of Ethnopharmacol. 2015; 174: 452-63.

5. Ospina LAF, Guerrero JPC, Buendia YCO, Bolívar IBP, Castillo FD. Actividad antiinflamatoria, antioxidante y antibacteriana de dos especies del género Tabebuia [Anti-inflammatory, antioxidant and antibacterial activity of two species of Tabebuia genus]. Rev Cubana de Pl Med. 2013; 18(1): 34-46.

6. Araújo MRS, Costa LPS, Chaves MH, editores. Análise fitoquímica das folhas de espécies da família Bignoniaceae [Phytochemical analysis of the leaves of Bignoniaceae family species]. Anais do $53^{\mathrm{a}}$ Congresso Brasileiro de Química. Rio de Janeiro, Rio de Janeiro. Brasil; 2013.

7. Collier HOJ, Dinneen LC, Johnson CA, Schneider C. The abdominal constriction response and its suppression by analgesic drugs in mice. British J of Pharmacol. 1968; 32: $285-310$.

8. Hunskaar S, Hole K. The formalin test in mice: dissociation between inflammatory pain. Pain. 1987; 30: 103-14.

9. Beirith A, Santos ARS, Calixto JB. Mechanisms underlying the nociception and paw edema caused by injection of glutamate into the mouse paw. Brain Res. 2002; 924: $219-28$.

10. Araújo EJF, Araújo DYML, Freitas RM, Pereira PMP, et al. Aspectos toxicológicos da planta medicinal Casearia sylvestris Swartz: revisão de literatura [Toxicological aspects of the medicinal plant Casearia sylvestris Swartz: a literature review]. Rev Ciênc Farm Básica Apl. 2014; 35 (3): 355-61.

11. Rogero SO, Lugão AB, Ikeda TI, Cruz AS. Teste in vitro de citotoxicidade: estudo comparativo entre duas metodologias [In vitro cytotoxicity test: a comparative study between two methodologies]. Material Res. 2003; 3(6): 317-20.

12. Vasconcelos CM, Vasconcelos TLC, Póvoas FTX, Santos RFEP, Maynart WHC, Almeida TG, et al. Antimicrobial, antioxidant and cytotoxic activity of extracts of Tabebuia impetiginosa (Mart. ex DC.) Standl. J of Chem and Pharm Res. 2014; 7(6): 2673-81.

13. González-Coloma A, Reina M, Sáenz C, Lacret R, Ruiz-Mesia L, Arán VJ, et al. Antileishmanial, antitrypanosomal, and cytotoxic screening of 
ethnopharmacologically selected Peruvian plants. Parasitol Res. 2012; 110(4): 138192.

14. Santos RFEP, Conserva LM, Bastos MLA, Campesatto EA. Avaliação do potencial biológico da Tabebuia aurea (Silva Manso) como fonte de moléculas bioativas para atividade antimicrobiana, antiedematogênica e antirradicalar [Evaluation of the biological potential of Tabebuia aurea (Silva Manso) as a source of bioactive molecules for antimicrobial, antidematogenic and antiradicalar activity]. Rev Bras Pl Med. 2015; 17(4): 1159-68.

15. Nascimento SS, Desantana JM, Nampo FK, Ribeiro EAN, Silva DL, AraújoJúnior JX, et al. Efficacy and safety of medicinal plants or related natural products for fibromyalgia: a systematic review. Evid Based Complement Alternat Med. 2013; 2013: $1-10$.

16. Chandrika PU, Rao AS, Chandra MSR, , Kambampati NVBLAB. Antinociceptive and anti-inflammatory activity of Tabebeuia aurea leaf extracts. Int $J$ of Ayurvedic and Herb Med. 2014; 4(4): 1520-6.

17. Lee MH, Choi HM, Hahm D, Her E, Yang H, Yoo MC, et al. Analgesic and antiin ammatory effects in animal models of an ethanolic extract of Taheebo, the inner bark of Tabebuia avellanedae. Mol Med Rep. 2012; 6: 791-96.

18. Regalado AI, Mancebo B, Paixão A, López Y, Merino N, Sánchez LM. Antinociceptive activity of methanol extract of Tabebuia hypoleuca (C. Wright ex Sauvalle) Urb. stems. Med Princ and Pract. 2017; 26: 368-74. 